\title{
Ethanolic Extract of Hedyotis corymbosa and Its Combination with 5-FU Inhibit Cyclin D Expression on WiDr Colorectal Cancer Cell
}

\author{
Argandita Meiftasari , Januar Caesar W. P, Annisa Novarina, Julika Yovi W, \\ Riris Istighfari Jenie*
}

Cancer Chemoprevention Research Center, Faculty of Pharmacy, Universitas Gadjah Mada, Yogyakarta, Indonesia

\begin{abstract}
Hedyotis corymbosa has been used for long time as an important component in several folklore medicine formula to clinically treat various types of cancer, including colorectal cancer (CRC). Previously, Hedyotis corymbosa ethanolic extract (HEE) which contain ursolic acid reported to inhibit CRC growth via induction of cancer cell apoptosis and blocked the cell cycle, preventing $G I$ to $S$ progression where cyclin D highly espressed in this phase. 5-fluorouracil (5FU), the first line chemotherapy of colorectal cancer have had resistence and possessed several side effects such as neutropenia, immunosuppression, diarrhea, and also constipation. Therefore, the aim of this research is to conduct the antiproliferative effect and molecular analysis of HEE and its combination with 5FU. Molecular docking study was also done to approach the specific protein target of the compound. Antiproliferative effect was conducted by MTT assay, while cyclin D expression was examined by immunofluorescence. The proliferative effect showed that both HEE and 5-FU had cytotoxic effect with $\mathrm{IC}_{50}$ value of $65 \mu \mathrm{g} / \mathrm{mL}$ and $90 \mu \mathrm{M}$ respectively, meanwhile the combination of $\mathrm{HEE}$ and 5FU have synergism effect with $\mathrm{Cl}=0.48$ on dose $\mathrm{HEE}=22 \mu \mathrm{g} / \mathrm{mL}$ and $5 \mathrm{FU}=6.25 \mu \mathrm{M}$. Immunofluorescence assay showed HEE and its combination with $5 \mathrm{FU}$ suppressed the expression of cyclin D. From molecular docking simulation, ursolic acid performed stable interaction with cyclin D. Our findings suggest that HEE may be an effective treatment for co-chemotherapic for 5-FU through inhibition of cyclin D expression.
\end{abstract}

Keywords : Hedyotis corymbosa, 5-fluorouracil, colorectal cancer, WiDr, cyclin D

\section{INTRODUCTION}

Cancer cells are characterized by uncontrolled proliferation (Hanahan and Weinberg, 2011), therefore inhibiting this excessive proliferation is one of the key for the development of anticancer drugs. The transition from $\mathrm{G} 1$ phase of the cell cycle to $\mathrm{S}$ phase plays crucial role for the control of eukaryotic cell proliferation, and its misregulation promotes oncogenesis. During G1 phase, growth dependent cyclin-dependent kinase (CDK) activity promotes DNA replication and initiates G1 to S phase transition (Bertoli, et al., 2013).

Colorectal cancer is one cancer type which becomes the third most commonly diagnosed cancer and the third leading cause of cancer death in both men and women. The prevalence of colorectal cancer has been incresed along the increasing human population (ACS, 2014). First line therapy for CRC, 5fluorouracil $(5 \mathrm{FU})$ has been become resistence despite its side effect like neutropenia, immunosuppression, cardiotoxicity and diarrhea (Denise, et al., 2015; Gressett, et al., 2006; Sorrentino, et al., 2012).

\footnotetext{
*Corresponding author e-mail : ririsjenie@gmail.com
} 
Recently, natural products have received great interest since they have relatively few side effects compared with modern chemotherapeutics and have been used clinically for thousands of years as significant alternative remedies for a variety of diseases including cancer (Kellof, 2000; Jeune, et al., 2005; Won, et al., 2006).

One promising medicinal plant is Hedyotis corymbosa that belongs to the Rubiaceae family and is widely distributed throughout Souteast Asia. Hedyotis corymbosa which contain ursolic acid that has been reported to inhibit the growth of CRC through the induction apoptosis and the blocked the cell cycle on G1/S progression (Suparman, 2008). To further exploration the activity of Hedyotis corymbosa ethanolic extract (HEE), we investigated its moleculer mechanism on the proliferation of human colon carcinoma WiDr cells through expression of cyclin D that regulated cell cycle on $\mathrm{G} 1 / \mathrm{S}$ progression.

\section{MATERIALS AND METHODS}

\section{Sample}

The herbs of Hedyotis corymbosa were collected from around Universitas Gadjah Mada, Sleman, Yogyakarta. The plant was determined in Biological Pharmacy Labroratorium, Faculty of Pharmacy Universitas Gadjah Mada. The air-dried and ground leaves $(300 \mathrm{~g})$ were soaked in ethanol $96 \%$ ( $3 \mathrm{~L}$ ) for $72 \mathrm{~h}$, then the mixture was filtered to obtain the crude extract. The extract was concentrated using rotary evaporator under vacuum at room temperature to obtain a final residue (23 g) for further experiment. Sample was dissolved in Dimethyl Sulfoxide (DMSO) (Sigma). Both $5 \mathrm{mg} / \mathrm{ml}$ 5-FU (Kalbe) and HEE were then diluted in cell culture medium before being applied. DMSO was also used as the cosolvent in dissolving samples in culture medium.

\section{Cell culture}

WiDr colorectal cells were obtained from Cancer Cancer Chemoprevention
Research Center, Yogyakarta. The cells were grown and maintained in Roswell Park Memorial Institute (RPMI) 1640 (Gibco) supplemented with $10 \% \mathrm{v} / \mathrm{v}$ Fetal Bovine Serum (FBS) (Sigma) and 1\% $10.000 \mathrm{UI} / \mathrm{mL}$ Penicillin-Streptomycin at $37^{\circ} \mathrm{C}$ in humidified atmosphere of $5 \% \mathrm{CO}_{2}$.

\section{MTT Cytotoxicity Assay}

Cell viability was determined by a microculture tetrazolium teachnique (MTT) assay according to the method by Mosmann (1983) with minor modifications. Briefly, WiDr cells were seeded into a 96-well plate $\left(8 \times 10^{3}\right.$ cells per well). After $48 \mathrm{~h}$ incubation with various concentration of $\mathrm{HEE}, 5-\mathrm{FU}$, and its combination, the medium was discarded and added with MTT reagent $(0.5 \mathrm{mg} / \mathrm{mL})$ (Biovision) $100 \mu \mathrm{L}$ to each well. The plate was incubated in a humidified atmosphere of 5\% $\mathrm{CO}_{2}$ at $37^{\circ} \mathrm{C}$ for $4 \mathrm{~h}$ and then formazan crystals were dissolved in $100 \mu \mathrm{L}$ of $0.01 \mathrm{~N} \mathrm{HCl}$ and incubated in the dark for overnight. The absorbance of cells was measured at $595 \mathrm{~nm}$ by a microplate reader. Cells absorbance was converted to \% cell viability. Linear regression between concentration and \% cell viability giving the equation $\mathrm{y}=\mathrm{Bx}+\mathrm{A}$ were used to calculate $\mathrm{IC}_{50}$ value, that is the concentration inhibiting 50\% cell proliferation.

\section{Immunofluorescence Assay}

Cells $\left(5 \times 10^{4}\right.$ cells/well) were seeded on coverslip in 24 well plates until $80 \%$ confluent. Cells were treated with fresh medium contain HEE, 5FU, and the combination and incubated in $37^{\circ} \mathrm{C}$ for $24 \mathrm{~h}$, cells were harvested and were washed using PBS and fixed it with $70 \%$ ethanol for $10 \mathrm{~min}$ at room temperature. After rinsed again with PBS, cells were incubated with blocking serum $1 \%$ BSA for $30 \mathrm{~min}$ at room temperature. Then, cells were incubated with primary antibody (anti-cyclin D) for 1 hour at room temperature. After rinsed with PBS, cells were incubated with secondary antibody conjugated by FITC for 1 hour at room temperature in the dark. Then, cell were added by DAPI solution and incubated for 10 
min at room temperature in the dark. After rinsed with PBS, cell were added with mounting solution (Fluoromount), put on slide glass, and store at $4{ }^{\circ} \mathrm{C}$. The protein expressions were observed under fluorescence microscope.

\section{RESULTS AND DISCUSSIONS}

\section{Hedyotis corymbosa, 5-FU, and their combination Inhibited the proliferation of WiDr Cells}

Cell viability assay was done to determine the inhibitory effect of HEE and 5FU single treatment on WiDr cells. The single treatment of 5-FU for $48 \mathrm{~h}$ with range of concentration up to $90 \mu \mathrm{M}$ revealed to possess cytotoxic effect in dose dependent manner. The cytotoxic effect was proven by morphological change on cells (shrinkage and fragmentation). Based on this study, 5-FU had cytotoxic effect by giving $\mathrm{IC}_{50}$ value of $90 \mu \mathrm{M}$. Interestingly, the treatment of single 5-FU in $24 \mathrm{~h}$ did not show significant inhibition on cells proliferation (data not shown), probably because of low sensitivity of WiDr cells toward 5-FU and high expression of timidilat sintetase (TS) on cells (Meyerhardt and Mayer, 2005; Giovannetti, et al., 2007). Moreover, 5-FU was also reported to induce NF- $\mathrm{KB}$ expression which regulated antiapoptosis transcription, causing cells were able to escape the apoptosis (Peters, et al., 2002).

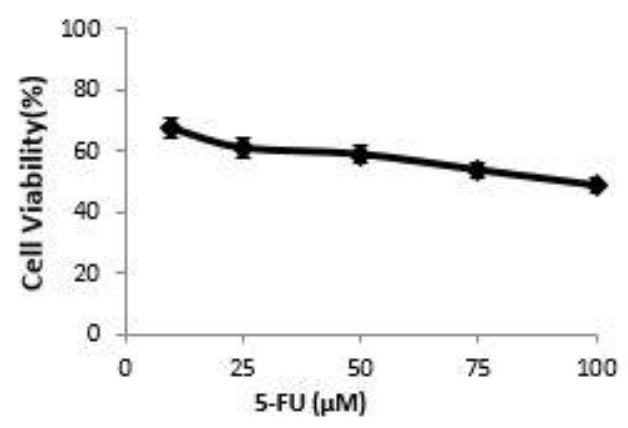

A

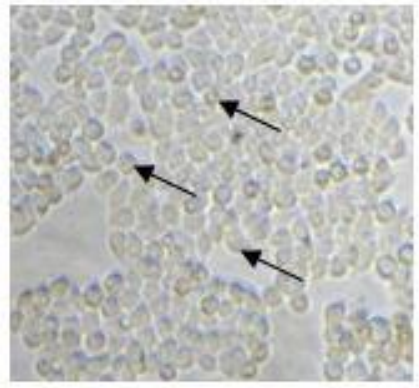

B

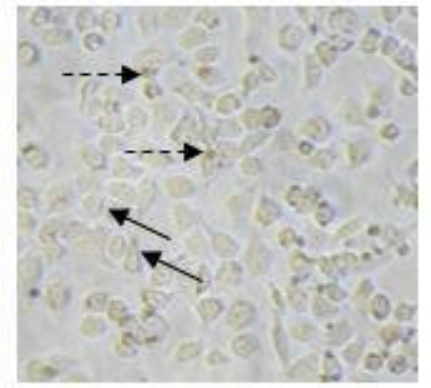

$\mathrm{C}$

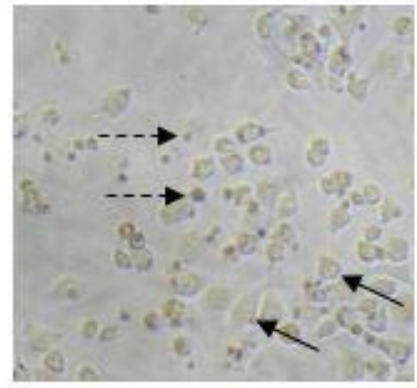

D

Figure I. Cytotoxic effect of 5-FU on WiDr cells. Briefly $8 \times 10^{3}$ WiDr cells/well were seeded in 96 well-plate and incubated for $24 \mathrm{~h}$ before treated with 5 -FU for $48 \mathrm{~h}$ as described in methods. Cells viability was determined by using MTT assay as described in the methods. (A) Cell viability profile after single treatment of 5 -FU for $48 \mathrm{~h}$ on $\mathrm{WiDr}$ cells. The cells morphological were shown above as (B) cell control, (C) $10 \mu \mathrm{M}$ of 5-FU, (D) $40 \mu \mathrm{M}$ of 5-FU. The cells were observe under inverted microscope with 100x magnification. Normal cells were marked as $\longrightarrow$ meanwhile irregular cells were marked as 
The cytotoxic effect of Hedyotis corymbosa ethanolic extract (HEE) was also carried out for $48 \mathrm{~h}$, based on several previous studies reported that the bioactive compound in HEE, ursolic acid revealed to give optimum cytotoxic effect after $48 \mathrm{~h}$ of treatment (DongKyoo, et al., 2000; Harmand, et al., 2005; Li, et al, 2010; Shisodia, et al., 2003). Similar to 5$\mathrm{FU}$, the treatment with HEE showed inhibitory effect in dose dependent manner; given $\mathrm{IC}_{50}$ value of $65 \mu \mathrm{g} / \mathrm{mL}$. The morphological changes on cells was seen in higher concentration of HEE, indicated that HEE possessed cytotoxic effect toward WiDr cancer cells.

Furthermore, the combination between HEE and 5-FU was carried out on WiDr cells to determine its combination effect on cells proliferation. Based on this study, the treatment of 5-FU and HEE exhibited synergistic effect on WiDr cells, given CI value less than 1 , with lowest CI value was showed in combination of $10 \mu \mathrm{g} / \mathrm{mL}$ HEE andd $1.25 \mu \mathrm{M}$ 5-FU with CI value of 0.33. Based on MTT assay, it was demonstrated that the treatment of HEE in combination with 5-FU inhibited cells proliferation significantly, as the single treatment with 5-FU only inhibit cells proliferation up to $40 \%$, when in combination with $40 \mu \mathrm{g} / \mathrm{mL}$ HEE could decreased cells viability up to $65 \%$. Thus, HEE could be applied as co-chemoterapeutic agent to increase 5-FU sensitivity on colon cancer.

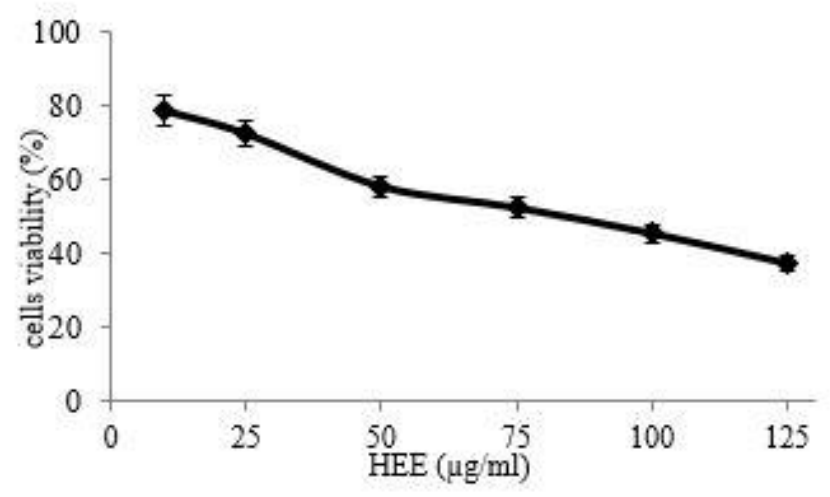

A

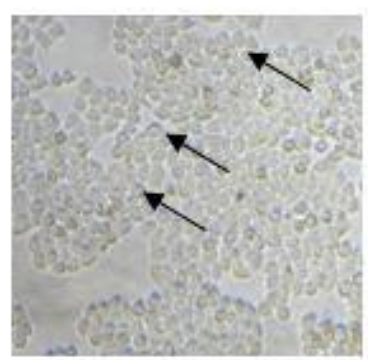

B

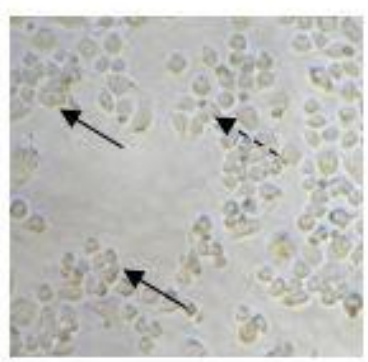

C

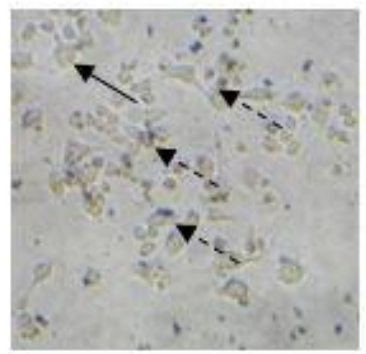

D

Figure 2. Cytotoxic effect of HEE on WiDr cells. Briefly $8 \times 10^{3} \mathrm{WiDr}$ cells/well were seeded in 96 well-plate and incubated for $24 \mathrm{~h}$ before treated with HEE for $48 \mathrm{~h}$ as described in methods. Cells viability was determined by using MTT assay as described in the methods. (A) Cell viability profile after single treatment of HEE for $48 \mathrm{~h}$ on WiDr cells. The cells morphological were shown above as (B) cell control, (C) $10 \mu \mathrm{g} / \mathrm{mL}$ of HEE, (D) $40 \mu \mathrm{M}$ of HEE. The cells were observe under inverted microscope with 100x magnification. 


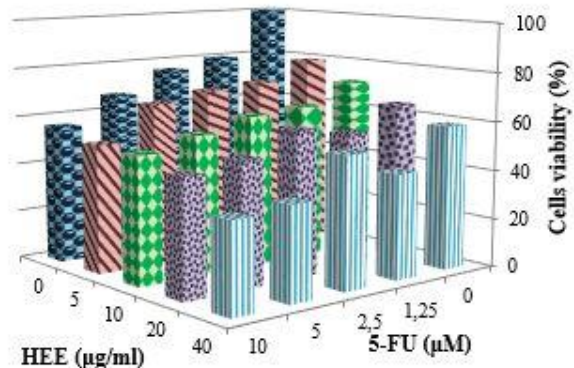

Figure 3. The combination treatment of HEE and 5-FU after $48 \mathrm{~h}$ on WiDr cells. Briefly, $10^{4} \mathrm{WiDr}$ cells/well were seeded in 96-wellplate before treated with HEE and 5-FU and incubated for next $48 \mathrm{~h}$ as described in methods. The effect of combination treatment was determined as $\%$ of cells viability $(n=3$, $p<0,05)$.

Table I. Combination Index $(\mathrm{Cl})$ value from combination treatment of HEE and 5-FU on WiDr cells for $48 \mathrm{~h}$

\begin{tabular}{ccccc}
\hline \multirow{2}{*}{ HEE $(\boldsymbol{\mu g} / \mathrm{ml})$} & \multicolumn{5}{c}{$\mathbf{5 - F U}(\boldsymbol{\mu M})$} \\
\cline { 2 - 5 } & $\mathbf{1 , 2 5}$ & $\mathbf{2 , 5}$ & $\mathbf{5}$ & $\mathbf{1 0}$ \\
\hline $\mathbf{5}$ & 0.86 & 0.61 & 0.82 & 0.60 \\
$\mathbf{1 0}$ & 0.33 & 0.41 & 0.48 & 0.66 \\
$\mathbf{4 0}$ & 0.36 & 0.53 & 0.50 & 0.67 \\
$\mathbf{4 0}$ & 0.43 & 0.67 & 0.51 & 0.65 \\
\hline
\end{tabular}

Previous study had been reported that HEE caused cell cycle arrest on G1/S phase. Further mechanism has been conducted to evaluate cyclin D expression which regulated cell cycle in $\mathrm{G} 1$ to $\mathrm{S}$ transition by using immunofluorescence assay.

This research suggests that HEE perform promising potency to be developed as cochemotherapeutic agent for CRC.
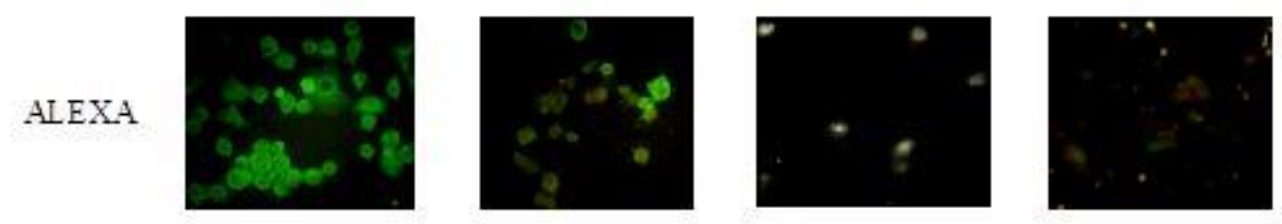

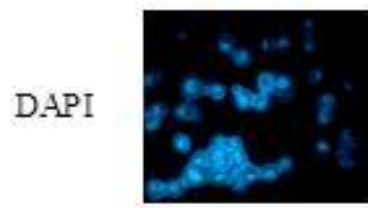

Control

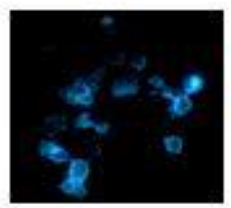

HEE

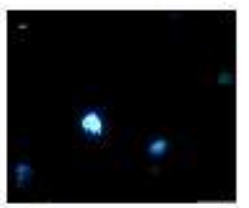

5-FU

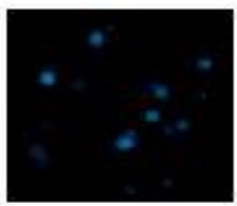

$\mathrm{HEE}+5-\mathrm{FU}$

Figure 4. Effect of 5-FU and HEE on cyclin D expression on WiDr Cells. Cells were gorwn on coverslips and treated with compounds as indicated in methods, then subjected to immunofluorescent staining with cyclin D and DAPI as described in materials and methods. Visualizations were done under microscope fluorescent with 400x magnification. 


\section{ACKNOWLEDGMENT}

This study was financially supported by Research Grant from Ministry of Research, Technology, and Higher Education of the Republic of Indonesia through the scheme of Program Kreativitas Mahasiswa Penelitian (PKM-P) 2014.

\section{REFERENCES}

American Cancer Society, 2014, Colorectal Cancer Facts \& Figures 2014-2016, Atlanta: American Cancer Society,

Bertoli, C., Skotheim, J.M. and de Bruin, R.A.M., 2013, Control of cell cycle transcription during $\mathrm{GI}$ and $\mathrm{S}$ phases, Nat. Rev. Mol. Cell Biol., I4(8), 5I8-528.

Nurse, P., 1994, Ordering S Phase and M Phase in the Cell Cycle, Cell, 79(4), 547-550.

Chen, Y. Robles, A.I., Martinez, L.A., Liu, F., Gimenez-Conti, I.B. and Conti, C.J., 1996, Expression of GI Cyclins, CyclinDependent Kinases, and CyclinDependent Kinase Inhibitors in Androgen-Induced Prostate Proliferation in Castrated Rats, Cell Growth Differ., 7, I57|-I578.

Denise, C., Paoli, P., Calvani, M., Taddei, M. L., Giannoni, E. and Kopetz, S., 2015, 5Fluorouracil Resistant Colon Cancer Cells are Addicted to Oxphos to Survive and Enhance Stem-Like Traits, Oncotarget, 6(39), 4I706-4I72I.

Giovannetti, E., Backus H.H.J., Wouters D., Ferreira C.G., van Houten V.M.M. and Brakenhoff R.H., 2007, Changes in the Status of p53 Affect Drug Sensitivity to Thymidylate Synthase (TS) Inhibitors by Altering TS Levels, British J. Can., 96(5), 769-775.
Graña, X. and Reddy, E.P., 1995, Cell Cycle Control in Mammalian Cells: Role of Cyclins, Cyclin Dependent Kinases (Cdks), Growth Suppressor Genes And Cyclin-Dependent Kinase Inhibitors (CKIs), Oncogene, I I(2), 2II-2I9.

Gressett, S.M., Stanford, B.L. and Hardwicke, F., 2006, Management of Hand-Foot Syndrome Induced by Capecitabine, J. Oncol. Pharm. Pract., | 2(3), |3|-|4|.

Kelloff, G.J., 2000, Perspectives on Cancer Chemoprevention Research and Drug Development, Adv Cancer Res., 78(4), 199-334.

Jeune, M.A., Kumi-Diaka, J. and Brown, J., 2005, Anticancer Activities of Pomegranate Extracts and Genistein in Human Breast Cancer Cells, J. Med. Food, 8(4), 469-475.

Meyerhardt, J.A. and Mayer, R.J., 2005, Systemic Therapy for Colorectal Cancer, $N$. Engl. J. Med., 352(5)-476-484.

Mosmann, T., 1983, Rapid Colorimetric assay for cellular growth and survival: Application to proliferation and cytotoxicity assay, J. Immunol. Methods, 65(I-2), 55-63.

Peters, G.J., Backus, H.H.J., Freemantle, S., van Triest, B., Pisanelli, G.C. and Wilt, C.L., 2002 , Induction of thymidylate synthase as a 5-fluorouracil resistannce mechanism, Biochimia et Biophysica Acta, I 587(2-3), 194-205.

Won, H.J., Han, C.H., Kim, Y.H., Kwon, H.J, Kim, B.W., Choi, J.S. and Kim, K.H., 2000 , Induction of apoptosis in human acute leukemia Jurkat $T$ cells by Albizzia julibrissin extract is mediated via mitochondria-dependent caspase-3 activation, J Ethnopharmacol, 106(3), 383-389. 